on the antigenic structure of bacteria by the application of the phagocytic reaction.

The experiments shed some light on the efficiency of the mechanism of phagocytosis depending on the character of infecting bacteria. They also suggest the importance of an as yet unknown factor, contained in the normal horse serum, for the phagocytic process of smooth bacterial forms.

The phagocytic test proved to be more sensitive than serological reactions in the detection of differences in the antigenic structure of bacteria (for example, in the detection of transitional forms).
S. SLOPEK
A. Skurski
E. Michalska

L. Dabrowski

Department of Bacteriology,

Institute of Immunology and Experimental Therapy,

Polish Academy of Sciences, Wrocław.

July 7.

\section{Longevity of Proteus Group of Amœbæ}

Explanation (I) of the findings described by Muggleton and Danielli ${ }^{1}$ appears to fit in best with the facts enumerated below.

The normal life-cycle of the Proteus group of amoebae consists of four well marked stages : (a) spore, (b) developing juvenile, (c) adolescent, (d) mature to senile. It is the adolescent and young adult that can be made to reproduce indefinitely by binary fission. As soon, however, as a rigid control of their environment is relaxed, they proceed with their life-cycle. Chromidia from the nucleus escape into the cytoplasm and develop into spores. When the individual becomes filled with spores it dies. If, however, these spore-filled individuals are placed in a Petri dish and killed by a change in $p \mathrm{H}$, the hatching of the spores, and their subsequent development, given a suitable pabulum, can be observed. It has been shown why this development is slow $^{2}$. I am at present engaged in trying to accelerate this growth, and am glad to record here the gift of supplies of bacteria and lettuce-water sent to me by Dr. Muriel Robertson of the Lister Institute.

Notre Dame Convent, MONICA TAYLOR

Dowanhill,

Glasgow, W.2. July 31.

${ }^{1}$ Muggleton, A., and Danielli, J. F., Nature, 181, 1738 (1958). 2
Taylor, M., Hayes, C., and Galbraith, M., Proc. Roy. Soc., Edin., B,
66, Part III, No. 15 (1957).

\section{Growth and Maturity of the Barnacles Lepas hillii and Lepas anatifera}

INFORMATION on the rate of growth of all species of Lepas is scanty. Stanley Kemp, in a letter to J. F. Anton ${ }^{\mathrm{I}}$, quotes three sources, the first of which, referring to an unspecified Lepas, gives an increase in capitulum length of about $1 \mathrm{~mm}$. a day; the second and third, referring to $L$. anserifera, give increases of $8 \mathrm{~mm}$. in 8 days, $21 \mathrm{~mm}$. in 40 days and $25 \mathrm{~mm}$. in 107 days. In all cases these are minimum rates since they refer to ships and to a buoy known to be free of barnacles at one date and supporting barnacles of quoted size at another, the moment of settling being unknown.
During the voyage of the yacht Petula from Dakar to Barbados in the winter of $1953-54^{2}$, colonies of barnacles settled on the ship's side above her antifouling paint and flourished there throughout the passage. While the ship lay in Dakar harbour preparing for sea, the stores which were loaded into her so increased her draught that some of her white topside paint was submerged, and here many fouling organisms were able to gain a hold. So long as the ship was at anchor only the sessile barnacle Balanus amphitrite Darw. was present, but at sea this species largely died off and was replaced by the pedunculate barnacles Lepas hillii Leach, Lepas anatifera L. and Conchoderma virgatum (Spengler). Conchoderma virgatum was present in large numbers and early attained a capitulum length of $9 \mathrm{~mm}$. but beyond this length it did not grow, being heavily preyed upon by the trigger fish Canthidermis maculatus and C. sobaco.

In position $15^{\circ} \mathrm{N}, 31^{\circ} \mathrm{W}$, after the ship had been at sea for 30 days, a sample of twenty of the largest Lepas growing on the topside was taken and preserved. A further sample of sixty of the largest specimens from an adjacent position was taken after 60 days, in position $15^{\circ} \mathrm{N}$., $46^{\circ} \mathrm{W}$.

Measurement of the preserved material yielded results summarized in Table 1 . The measurements, to the nearest $0.5 \mathrm{~mm}$., were made from the umbo (basioccludent angle) of the scutum to the upper (occludent) tip of the tergum. This dimension may be approximately equated with the capitulum length generally quoted in the literature, being very slightly greater ; it is to be preferred to the capitulum length as giving a firmer standard of size.

Table 1. Length Distribution of Lepas taken 30 and 60 Days

\begin{tabular}{|c|c|c|c|c|c|}
\hline & Length (mm.) & $11-13 \cdot 5$ & $14-16 \cdot 5$ & $17-19 \cdot 5$ & $20-23$ \\
\hline $\begin{array}{c}30 \\
\text { days } \\
60 \\
\text { days }\end{array}$ & $\left\{\begin{array}{l}\text { Total } L . \text { hillii } \\
\text { Gravid } L . \text { hillii } \\
\text { Total } L . \text { anatifera } \\
\text { Gravid } L \text {. anatifera } \\
\text { Total } L . \text { hillii } \\
\text { Gravid } L . \text { hillii } \\
\text { Total } L . \text { anatifera } \\
\text { Gravid } L \text {. anatifera }\end{array}\right.$ & $\begin{array}{l}3 \\
0 \\
5 \\
0 \\
6 \\
0 \\
0 \\
0\end{array}$ & $\begin{array}{r}4 \\
1 \\
6 \\
2 \\
10 \\
2 \\
0 \\
0\end{array}$ & $\begin{array}{r}2 \\
0 \\
0 \\
0 \\
20 \\
16 \\
1 \\
0\end{array}$ & $\begin{array}{r}0 \\
0 \\
0 \\
0 \\
21 \\
11 \\
2 \\
1\end{array}$ \\
\hline
\end{tabular}

The age of the barnacles in the samples is again not known with certainty since settlement on the ship's side was not observed. Colonies containing both species of Lepas were established 10 days out, with capitula of perhaps $5 \mathrm{~mm}$., and from the first day out the ship passed among much flotsam bearing mature $L$. anatifera from which infection by this species could have occurred. No $L$. hillii were found on collected flotsam, yet it is certain that both species were well established on the tenth day and it is not unreasonable to suppose that settlement of both began very near to the start of the voyage.

All specimens were opened and searched for embryos. From Table 1 the following may be noted.

(a) Among the 30-day group only one specimen of $L$. anatifera among eleven and one of $L$. hillii among nine bore embryos in the ovigerous lamellæ. It therefore seems probable that both species require more than 30 days on average from settlement to maturity.

(b) Of the 60-day group of $L$. antifera one out of three bore embryos. Twenty-nine out of fifty-seven $L$. hillii bore embryos, all except two of the gravid examples being longer than $16.5 \mathrm{~mm}$. So large a proportion of the barnacles between 17 and $19 \cdot 5 \mathrm{~cm}$. 